REGARDS

SUR LEECONOMIE ALLEMANDE

BULLETIN ECONOMIQUE DU CIRAC

\section{Regards sur l'économie allemande}

Bulletin économique du CIRAC

$81 \mid 2007$

Varia

\title{
Corporate Governance
}

GERUM Elmar, Das deutsche Corporate Governance-System. Eine empirische Untersuchung

\section{(2) OpenEdition}

Journals

Édition électronique

URL : http://journals.openedition.org/rea/439

DOI : $10.4000 /$ rea.439

ISBN : 978-2-8218-0858-4

ISSN : 1965-0787

Éditeur

CIRAC

Édition imprimée

Date de publication : 1 mai 2007

ISSN : 1156-8992

Référence électronique

"Corporate Governance», Regards sur l'économie allemande [En ligne], 81 | mai 2007, document 1, mis en ligne le 23 avril 2008, consulté le 22 septembre 2020. URL : http://journals.openedition.org/rea/439 ; DOI : https://doi.org/10.4000/rea.439

Ce document a été généré automatiquement le 22 septembre 2020

(C) CIRAC 


\section{Corporate Governance}

GERUM Elmar, Das deutsche Corporate Governance-System. Eine empirische Untersuchung

\section{RÉFÉRENCE}

GERUM Elmar, Das deutsche Corporate Governance-System. Eine empirische

Untersuchung, Schäffer Poeschel Verlag, Stuttgart, 2007, 494 p.

1 Le modèle « rhénan » de la gouvernance des entreprises serait-il en train de perdre sa spécificité sous l'influence du modèle anglo-saxon? Cette interrogation récurrente dans le débat public outre-Rhin est au cœur de cette étude empirique menée auprès de 400 sociétés par actions. Elle parvient au constat que le système de gouvernance allemand se caractérise au contraire par sa "continuité dans un changement modéré » : bien qu'on observe une certaine convergence au niveau de la pratique du pilotage des sociétés, les structures du "capitalisme rhénan » se sont, elles, consolidées au fil du temps. (ib) 